\title{
Oppdragsdokument 2014
}

\section{Helse Sør-Øst RHF}

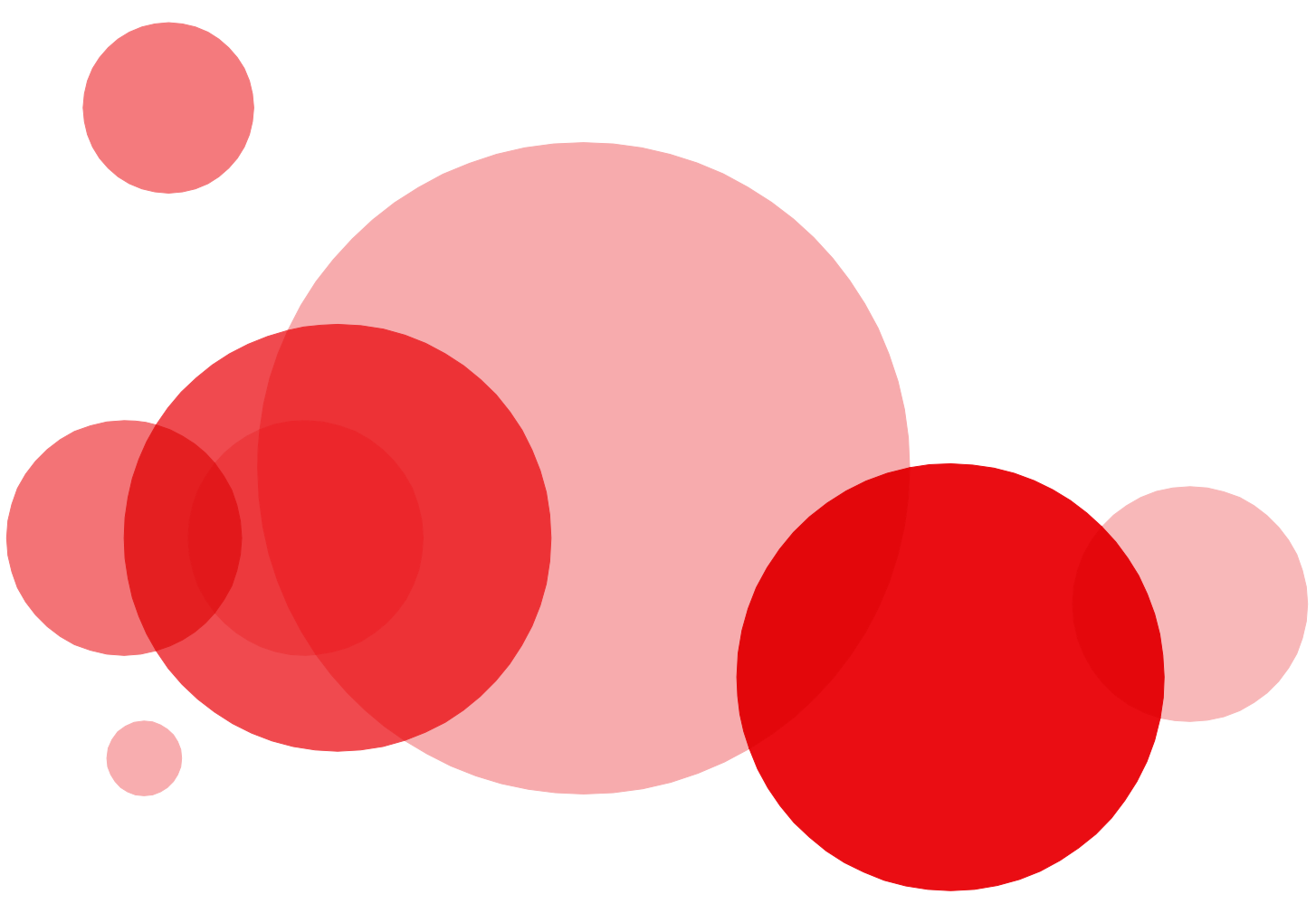

Oppdatert: 9.1.2014

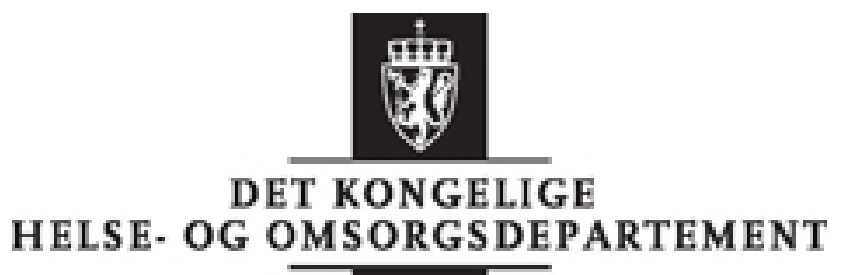




\section{Innhold}

1. Innledning 3

2. Tildeling av midler 4

3. Aktivitet $\quad 7$

4. Tilgjengelighet og brukerorientering $\quad 7$

5. Kvalitet og pasientsikkerhet 8

6. Personell, utdanning og kompetanse 9

7. Forskning og innovasjon 10

8. Styringsparametre $2014 \quad 10$

9. Oppfølging og rapportering 12 


\section{Innledning}

Helse- og omsorgsdepartementet stiller gjennom oppdragsdokumentet midlene Stortinget har bevilget til Helse Sør-Øst RHF for 2014 til disposisjon. Helse Sør-Øst RHF skal utføre pålagte oppgaver og gjennomføre styringskravene innenfor de rammer og ressurser som blir stilt til rådighet i dokumentet. Departementet forutsetter at Helse Sør-Øst RHF setter seg inn i Prop. 1 S (2013-2014), Prop. 1 S Tillegg 1 (2013-2014) og Stortingets budsjettvedtak.

Staten har det overordnede ansvaret for at befolkningen gis nødvendig spesialisthelsetjeneste. Helse Sør-Øst RHF har ansvar for at befolkningen i regionen får tilgang til spesialisthelsetjenester slik dette er fastsatt i lover og forskrifter. Helse Sør-Øst RHF har ansvaret for at forskning, utdanning og opplæring av pasienter og pårørende ivaretas på en god måte, og at disse oppgavene underbygger god og forsvarlig pasientbehandling. Helse SørØst RHF skal sikre tilstrekkelig kompetanse i alle deler av spesialisthelsetjenesten. Det skal legges vekt på likeverdige helsetjenester og arbeid for å redusere sosiale helseforskjeller i aktuelle befolkningsgrupper, herunder innvandrergrupper. Pasienter og brukere må ha trygghet for at tjenestene er tilgjengelige, og at de blir møtt med omsorg og respekt. I dette ligger at det skal brukes kvalifiserte tolker ved behov.

Samiske pasienters rett og behov for tilrettelagte tjenester må etterspørres og synliggjøres fra planleggingsfasen, gjennom utredningsfasen, og når beslutninger tas.

Styring og kontroll med kvalitet og pasientsikkerhet er sentralt. Styret og ledelsen i Helse SørØst RHF har også et ansvar for å følge med på kvalitetsindikatorene som Helsedirektoratet publiserer og eventuelt iverksette tiltak for å forbedre kvaliteten i tjenestene, jf. Sak 7 Oppfølging av Meld. St. 10 (2012-2013) - styrenes og ledelsenes ansvar for gjennomgang av virksomheten i foretaksprotokoll av 23.5.2013 til Helse Sør-Øst RHF.

Hovedoppgavene i spesialisthelsetjenesten skal løses ved de offentlige sykehusene. Det er en utfordring at mange pasienter venter unødvendig lenge på nødvendig behandling, også på helsetjenester der det er ledig kapasitet hos private aktører. Helse Sør-Øst RHF må sørge for mer bruk av private aktører der dette bidrar til å redusere ventetidene på en kostnadseffektiv måte. Helse Sør-Øst RHF skal raskt utnytte kapasitet innenfor eksisterende avtaler og anskaffelsesregelverk, og de private skal sikres forutsigbarhet og langsiktighet ved gjennomføring av anskaffelser.

Samhandlingsreformen, Nasjonal helse- og omsorgsplan og Stortingets behandling (Innst. 212 S (2009-2010) og Innst. 422 S (2010-2011)) utgjør et overordnet rammeverk og gir føringer for den videre utvikling av den samlede helse- og omsorgstjenesten. Gode pasientforløp og flere tjenester nær der pasientene bor er sentrale mål. De regionale helseforetakene skal bidra til å desentralisere spesialisthelsetjenester der dette er hensiktsmessig, samt bidra til å utvikle og styrke den kommunale helse- og omsorgstjenesten. Viktige virkemidler er samarbeidsavtalene og spesialisthelsetjenestens veiledningsplikt overfor de kommunale helseog omsorgstjenestene. Omstilling av tjenester innen somatikk, psykisk helsevern, rusbhandling og rehabilitering som berører kommunene skal synkroniseres slik at de ikke gjennomføres før kommunene er i stand til å håndtere de nye oppgavene. Det er en forutsetning at omstillingene gir brukerne et kontinuerlig og like godt eller bedre tjenestetilbud enn tidligere. Det forutsetter et nært samarbeid mellom regionale helseforetak/foretak og kommunene, samt brukerne og deres organisasjoner.

Tjenestene innen psykisk helsevern og tverrfaglig spesialisert rusbehandling skal være samordnet og tilpasset pasienter med sammensatte lidelser. Det er et mål at forpliktende 
samhandling i tjenestene styrkes, både innad i spesialisthelsetjenesten og mellom spesialisthelsetjenesten og kommunene. Tjenestene bør fortrinnsvis tilbys nært pasientens bosted. Det er et mål at poliklinisk oppbygging innen rusbehandling ikke går på bekostnng av døgnbehandling der det trengs.

Følgende nye strategier og handlingsplaner fra Helse- og omsorgsdepartementet skal legges til grunn for utvikling av tjenestetilbudet:

- Sammen - mot kreft, Nasjonal kreftstrategi 2013-2017

- Likeverdige helse- og omsorgstjenester - god helse for alle, Nasjonal strategi om innvandreres helse 2013-2017

- NCD-strategi, For forebygging, diagnostisering, behandling og rehabilitering av fire ikke-smittsomme folkesykdommer; hjerte- og karsykdommer, diabetes, kols og kreft 2013-2017

Helsedirektoratet har ansvar for kvalitetsindikatorer. Et utvalg av kvalitetsindikatorene er valgt som styringsparametre for departementets oppfølging av de regionale helseforetakene, jf. kap. 8. Styringsparametrene skal gi et mest mulig samlet bilde av kvalitet, pasientsikkerhet og brukerorientering i tjenesten. Helsedirektoratet skal med bakgrunn i alle

kvalitetsindikatorene varsle departementet dersom indikatorene gir holdepunkter for kvalitetsbrist eller uønsket variasjon i kvalitet. Departementet vil i oppfølgingsmøtene med de regionale helseforetakene følge opp de valgte styringsparametrene og andre kvalitetsindikatorer ved behov.

\section{Tildeling av midler}

Grunnlaget for Helse Sør-Øst RHFs inntekter er i hovedsak bevilgningsvedtak i

Stortinget. Helse Sør-Øst RHF skal benytte midlene som stilles til rådighet på en effektiv måte og slik at de kommer pasientene til gode. Helse Sør-Øst RHF skal i 2014 basere sin virksomhet på tildelte midler i tabell 1. Plan for utbetalinger av tilskudd kommer i eget brev.

Det vises til helseforetaksloven $\S 45$ samt Bevilgningsreglementet $\S 10$, der departementet og Riksrevisjonen kan iverksette kontroll med at midlene nyttes etter forutsetningene.

Tabell 1. Tilskudd til Helse Sør-Øst RHF fordelt på kapittel og post (i 1000 kroner)

\begin{tabular}{|r|l|l|r|}
\hline Kap & Post & Betegnelse & $\begin{array}{l}\text { Helse Sør- } \\
\text { Øst RHF }\end{array}$ \\
\hline 732 & 70 & Tilskudd til helseforetakene (Omlegging av arbeidsgiveravgift) & 22777 \\
\hline & 70 & Tilskudd til helseforetakene (Modum bad) & 1100 \\
\hline & 70 & Tilskudd til helseforetakene (Tilskudd til turnustjeneste) & 14100 \\
\hline & 70 & Tilskudd til helseforetakene (Ny særreaksjonsordning, herunder register) & 1600 \\
\hline & 70 & Tilskudd til helseforetakene (Kreftregisteret) & 102600 \\
\hline & 70 & Tilskudd til helseforetakene (Pilotprosjekt screeening kolorektal kreft) & 40900 \\
\hline & 70 & Tilskudd til helseforetakene (Narkolepsi på barn) & 3100 \\
\hline & 70 & Tilskudd til helseforetakene (Doping) & 4100 \\
\hline & 70 & Tilskudd til helseforetakene (Nytt nødnummer) & 900 \\
\hline & 70 & Tilskudd til helseforetakene (Dropouts) & 4000 \\
\hline & 70 & Tilskudd til helseforetakene (Forskningsstudie ipilimumab) & 110000 \\
\hline & 70 & Tilskudd til helseforetakene (Prostatasentre) & 6200 \\
\hline & 70 & Tilskudd til helseforetakene (Nødnett - innføringskostnader i kommunene) & 110000 \\
\hline & 70 & Tilskudd til helseforetakene (Studie biotilsvarende legemidler) & 20000 \\
\hline & 71 & Kvalitetsbasert finansiering & 241900 \\
\hline
\end{tabular}




\begin{tabular}{|l|l|l|r|}
\hline Kap & Post & Betegnelse & $\begin{array}{l}\text { Helse Sør- } \\
\text { Øst RHF }\end{array}$ \\
\hline & 72 & Tilskudd til Helse Sør-Øst RHF & 46875111 \\
\hline & 76 & Innsatsstyrt finansiering av sykehus, overslagsbevilgning & 1 \\
\hline & 77 & Refusjon poliklinisk virksomhet ved sykehus, overslagsbevilgning & 617700 \\
\hline & 78 & Forskning og nasjonale kompetansetjenester & 270400 \\
\hline & 79 & Raskere tilbake & 115854 \\
\hline 733 & 70 & Behandlingsreiser til utlandet & 3800 \\
\hline 770 & 21 & $\begin{array}{l}\text { Spesielle driftsutgifter (Forsøksordning tannhelsetjenester i tverrfaglig } \\
\text { miljø) }\end{array}$ \\
\hline
\end{tabular}

Kap 732, post 70 Studie biotilsvarende legemidler

Helse Sør-Øst RHF tildeles 20 mill. kroner som bidrag til en klinisk multisenter studie på biotilsvarende legemidler gjennom NorCRIN-nettverket. Studien skal gjennomføres av de fire regionale helseforetakene, under ledelse av Helse Sør-Øst HRF.

Kap. 732, post 72 Basisbevilgning Helse Sør-Øst RHF

Basisbevilgningen skal legge grunnlaget for å realisere de helsepolitiske målsetningene i spesialisthelsetjenesten. Midler til vedlikehold av og investeringer i bygg og utstyr inngår i basisbevilgningen.

Basisbevilgningen styrkes med 137,6 mill. kroner til økt kjøp fra private virksomheter innenfor områdene psykisk helsevern, rus og rehabilitering. Dette kommer i tillegg til målet innenfor TSB for 2014 på om lag 110 plasser fra ideelle virksomheter.

Basisbevilgningen styrkes slik at kjøpet av MR-undersøkelser fra private radiologiske virksomheter kan økes med 10 pst. Så langt som mulig bør økt kjøp skje innenfor eksisterende avtaler slik at tiltaket får raskest mulig virkning.

Helse Sør-Øst RHF forutsettes å inngå avtaler med private opptrenings- og rehabiliteringsinstitusjoner. Det må også vurderes behov for kjøp av tjenester utenfor egen region. Egenandelen i private opptrenings- og rehabiliteringsinstitusjoner er 128 kroner pr døgn for opphold fra 1. januar 2014. Egenandelen gjelder også for dagopphold.

Helse Sør-Øst RHF skal sette av minst 234,1 mill. kroner av basisbevilgningen til etablering av døgntilbud øyeblikkelig hjelp i kommunene, og bidra til at tilbudene i kommunene har en kvalitet som reelt sett avlaster sykehus. Tidspunkt for utbetaling av bidrag avtales lokalt eller utbetales når tilbudet starter opp. Nye øyeblikkelig hjelp døgnopphold er et viktig virkemiddel for kommunene til å kunne påvirke sykehusforbruket. Nye øyeblikkelig hjelp døgnopphold i kommunene inngår ikke i kommunal medfinansiering.

Betalingssatsen for kommunene for utskrivningsklare pasienter er 4255 kroner i 2014.

Helse Sør-Øst RHF skal sette av minst 8 mill. kroner av basisbevilgningen til forskning om samhandling med de kommunale helse- og omsorgstjenestene.

Midler til Barn som pårørende, Nasjonalt klinisk nettverk for spiseforstyrrelser, Kompetansentrene for sikkerhets-, fengsels- og rettspsykiatri, Stifinnern, Rusmestringsenheter

\footnotetext{
${ }^{1}$ Posten er beskrevet under tabellen.

${ }^{2}$ Posten er beskrevet under tabellen.
} 
i fengsel, Soningenheter for personer under 18 år og Narkotikakontroll for domstolskontroll inngår i basisbevilgningen og skal videreføres på minst samme nivå som i 2013. Midler til Barn som pårørende er styrket i 2014, og Helse Sør-Øst RHF skal sette av 1 mill. kroner til læringsnettverk for alle lavterskeltiltak.

De regionale helseforetakene har hatt ansvaret for å dekke medikamentkostnader LAR. Fra 2014 vil de regionale helseforetakene også få ansvaret for å dekke utleveringskostnadene i LAR, med unntak for pasienter som oppfyller kriterier for å få utlevert medikamenter av kommunale tjenester, slik det fremgår av Prop. 1 S (2013-2014).

Finansieringen av de tre kreftlegemidlene vemurafenib (Zelboraf), abirateron (Zytiga) og denosumab (Xgeva) flyttes fra folketrygden til de regionale helseforetakene, jf. omtale i Prop. 1 S (2013-2014).

Ressursrammen legger til rette for en generell vekst i pasientbehandlingen på om lag 2,6 pst. fra 2013 til 2014. Aktivitetsveksten på om lag 1,6 pst. (inkl. døgntilbud øyeblikkelig hjelp i kommunene) innen innsatsstyrt finansiering (post 76) og 6,5 pst. innen refusjoner for poliklinisk behandling (post 77) måles i forhold til prognoser per 1. tertial 2013 og september 2013. Dersom veksten i 2013 blir høyere enn dette, vil veksten i 2014 bli tilsvarende lavere. Den generelle veksten omfatter også behandling som i all hovedsak finansieres av basisbevilgningen (f.eks. rehabilitering, psykisk helsevern og tverrfaglig spesialisert rusbehandling).

Kap. 732, post 76 Innsatsstyrt finansiering av sykehus, overslagsbevilgning ISF-satsen økes til 50 pst. Kap. 732, post 76 er en overslagsbevilgning. Samlet utbetaling over de aktivitetsbaserte ordningene skjer på grunnlag av registrert aktivitet. Dette innebærer at departementet på forhånd ikke vet hvor store utbetalingene over denne posten vil bli. I 2014 utgjør akontoutbetalingene over kap. 732, post 76 til Helse Sør-Øst RHF 12 752,2 mill. kroner.

A kontobeløpet er basert på en prognose for aktivitet per 1. tertial 2013, og det er dette nivået det er lagt til rette for å videreføre og øke med 1,6 pst. i 2014. Akontobeløpet er basert på en anslått samlet DRG-produksjon på 774425 DRG-poeng. I

aktivitetsbestillingen (målt i DRG-poeng) er det gjort fratrekk for nytt døgntilbud for øyeblikkelig hjelp i kommunene. Dette er anslått til å utgjøre om lag 0,8 pst. av ISFaktiviteten. Dersom det ikke blir etablert tilbud som forutsatt i kommunene, vil departementet tilbakeføre ubrukte tilskudd (kap. 762, post 60) til Helse Sør-Øst RHF (kap. 732, post 70 og kap. 732, post 76). Akontoutbetalingene baserer seg på en enhetspris på 40772 kroner.

Kap. 732, post 77 Refusjon poliklinisk virksomhet ved sykehus mv., overslagsbevilgning Kap. 732, post 77 er en overslagsbevilgning. Samlet utbetaling over posten skjer på grunnlag av registrert aktivitet. En aktivitet i tråd med Innst.11 S (2013-2014) tilsier en utbetaling på 1809 mill. kroner til Helse Sør-Øst RHF. Beløpet er basert på en prognose fra regnskapstall t.o.m. september 2013, og det er dette nivået som kan videreføres og økes i 2014. Samlet sett tar bevilgningen høyde for en vekst i poliklinisk aktivitet på 6,5 pst.

Kap 732, post 78 Forskning

Tilskuddet til forskning er styrket med 50,4 mill. kroner til Helse Sør-Øst RHF. Midlene skal benyttes til flerregionale kliniske forskningsprosjekter forankret i alle de regionale 
helseforetakene innenfor satsingsområdene hjerte- og karsykdommer (unikard), muskel- og skjelettplager, alvorlige psykiske lidelser, helsetjenesteforskning, kreftforskning, nevrologiske sykdommer inkludert demens (Nevronor), samt smerte- og utmattelsessykdommer som CFS/ME, borreliose, fibromyalgi mv.

Kap. 732 post 79 Raskere tilbake

Helse Sør-Øst RHF tildeles inntil 270,4 mill. kroner, herunder 8,4 mill. kroner til de arbeidsmedisinske avdelingene. Reell aktivitet vil avgjøre endelige inntekter innenfor rammen. Departementet vil vurdere a konto-beløpets størrelse mot rapportert aktivitet.

Kap. 733, post 70 Behandlingsreiser til utlandet

Helse Sør-Øst RHF skal sørge for behandlingsreiser til utlandet for 3000 pasienter.

Egenandelen er på 107 kroner per døgn for voksne pasienter og barns ledsagere, og inngår i egenandelstak 2.

Kap. 770, post 21 Forsøksordning tannhelsetjenester i tverrfaglig miljø Helse Sør-Øst RHF tildeles 3,8 mill. kroner. Formålet er å få kunnskap om behovet for odontologiske tjenester hos sykehuspasienter, og gi nødvendig undersøkelse og behandling. I tillegg skal det gis spesialiserte odontologiske tjenester til direktehenviste pasienter.

Helsedirektoratet gir faglig bistand ved etablering. Det tas sikte på å utvide prosjektet til også å omfatte Lovisenberg sykehus i 2014. Forsøket finansieres gjennom tilskudd fra kap. 770, post 21. Behandlinger kan finansieres etter poliklinikkforskriften eller gjennom folketrygdens stønadsordning etter Forskrift om stønad til dekning av utgifter til undersøkelse og behandling hos tannlege og tannpleier for sykdom (kap. 2711, post 72). For behandling finansiert over kap. 770 eller kap. 2711, post 72 er det ikke et vilkår at pasient er henvist fra lege. Tjenester som finansieres over disse kapitler gis vederlagsfritt. I forsøksperioden rapporteres aktiviteten direkte til Helsedirektoratet.

\section{Aktivitet}

Mål 2014:

- Budsjettert aktivitet på ISF (kap. 732.76) og polikliniske refusjoner (kap. 732.77) er i tråd med bestillingen.

\section{Tilgjengelighet og brukerorientering}

\section{Langsiktige mål:}

- Reduserte ventetider.

- Gode og effektive pasientforløp.

- Pasienter og brukere opplever god kvalitet og service.

- Pasienter og brukere medvirker aktivt i utformingen av eget behandlingstilbud

- Pasienters og brukeres erfaringer brukes aktivt i utforming av tjenestetilbudet

Mål 2014:

- Gjennomsnittlig ventetid i spesialisthelsetjenesten er under 65 dager.

- Ingen fristbrudd.

- Redusert ventetid, økt kapasitet og god kompetanse innen brystrekonstruksjon for pasienter med brystkreft.

- Alle ventetider på frittsykehusvalg.no er oppdatert månedlig.

- 80 \% av kreftpasienter har startet behandling innen 20 dager fra mottatt henvisning 
- Det er etablert minst ett tverrfaglig diagnosesenter for pasienter med uavklart tilstand i hver helseregion.

- Det er etablert minst to prostatasentre i Helse Sør-Øst.

- Det er gjennomført lokale pasienterfaringsundersøkelser på behandlingsenhetsnivå, resultatene er offentliggjort på helseforetakenes nettsider og aktivt fulgt opp i tjenesten.

- Det er etablert brukerstyrte plasser innen psykisk helsevern og tverrfaglig spesialisert rusbehandling i alle helseforetak.

- Det er etablert flere standardiserte pasientforløp i henhold til nasjonale retningslinjer for de ulike fagområdene.

- Det er oppnevnt koordinator for pasienter med behov for komplekse eller langvarige og koordinerte tjenester.

\section{Kvalitet og pasientsikkerhet}

\section{Langsiktige mål:}

- Bedre behandlingstilbud, økt overlevelse og mindre variasjon i resultat mellom sykehusene.

- Helseforetakene har bidratt til å styrke den kommunale helse- og omsorgstjenesten, i tråd med intensjonen i Samhandlingsreformen.

- Helseforetakene har implementert sentrale anbefalinger i relevante nasjonale faglige retningslinjer.

- Andel forebyggbare pasientskader er redusert med 50 prosent innen fem år, målt ut fra GTT-undersøkelsen for 2012.

- Sykehusene ivaretar oppgaver innen psykisk helsevern som bare kan utføres på sykehusnivå, dvs sikkerhetsavdelinger, lukkede akuttavdelinger og enkelte avgrensede spesialfunksjoner.

- Riktig og redusert bruk av tvang innen psykisk helsevern.

- Økt kapasitet i tilbudet til personer med rusmiddelavhengighet.

\section{Mål 2014}

- Pasientsikkerhetsprogrammets tiltakspakker inngår som en del av sykehusenes ordinære aktivitet og resultatene følges opp i ledelseslinjen.

- Kvalitetsindikatorer og ventetider som rapporteres til Helsedirektoratet, inkludert til fritt sykehusvalg, er rapportert på sykehusnivå.

- Medisinske kvalitetsregistre med nasjonal status har:

o nasjonal dekningsgrad

o omfatter pasientrapporterte effektmål

o benyttes til regelmessig evaluering av klinisk praksis, systematisk forbedringsarbeid og forskning.

- Det er etablert en enhetlig og kunnskapsbasert praksis for innføring av nye metoder i spesialisthelsetjenesten.

- Det er etablert flere øyeblikkelig hjelp døgntilbud i kommunene i samarbeid mellom helseforetak og kommuner.

- Det er høyere vekst innen psykisk helsevern og rusbehandling enn for somatikk på regionnivå. Det legges til grunn at veksten innen psykisk helsevern skjer ved DPS og innenfor psykisk helsevern for barn og unge. DPS skal bygges ut og utrustes til å ta ansvar for gode akuttjenester gjennom døgnet, ambulante tjenester, poliklinikk og 
døgnbehandling, slik at befolkningens behov for vanlige spesialisthelsetjenester er dekket. Veksten måles blant annet gjennom endring kostnader, ventetid og aktivitet.

- Andel årsverk DPS har økt i forhold til antall årsverk innen psykisk helsevern i sykehus.

- Andel tvangsinnleggelser for helseregionen er redusert med $5 \%$ sammenliknet med 2013.

- Døgnkapasiteten innen TSB er økt med om lag 110 plasser utover den kapasitet som gjeldende avtaler representerer for 2013. Plassene skal kjøpes fra ideelle virksomheter. Plassene skal bidra til mer mangfold i behandlingstilbudet, sikre at alle regioner har avtaler om TSB-plasser der rusfrihet er et mål i behandlingen (ikke LAR) og at det er tilgjengelige plasser innenfor behandlingsmetoden terapeutiske samfunn $\mathrm{i}$ alle regioner. Innkjøpet skal gjøres så raskt som mulig i 2014. Plassene skal kjøpes til følgende pasientgrupper:

o Langtidsplasser for rusavhengige

o Pasienter med samtidig rus- og psykiske lidelser

o Akutt- og abstinensbehandling

o Gravid/familier med rusproblemer

o Unge med mer omfattende hjelpebehov

- Det er etablert to dropout team for rusavhengige i Helse Sør-Øst.

- Det er i samarbeid med kommunene og brukerorganisasjonene etablert et effektivt og brukerorientert utrednings- og behandlingsforløp for pasienter med langvarige smerteog utmattelsestilstander der årsaken er uklar.

- Helse Sør-Øst RHF har inngått avtale med Helse Nord RHF om behandlingstilbud til samiske pasienter ved Samisk nasjonalt kompetansetjeneste - psykisk helsevern og rus (SANKS).

\section{Personell, utdanning og kompetanse}

Langsiktige mål

- Tilstrekkelig kvalifisert kompetanse og bedre utnyttelse av de samlede personellressursene.

- Utdanningsoppgaver er godt ivaretatt.

- Rekruttere, beholde og utvikle kompetanse hos medarbeidere i spesialisthelsetjenesten og sikre bærekraftig utvikling.

\section{Mål 2014}

- Gjennomføre analyser og utarbeide planer for håndtering av behov for personell. Særlig innsats må rettes mot behovet for spesialisert kompetanse for å sikre gode tjenestetilbud.

- Tilstrekkelig antall utdanningsstillinger for legespesialister, også innenfor den nye spesialiteten i rus- og avhengighetsmedisin som ventes godkjent i 2014.

- Redusere omfanget av midlertidige stillinger i helseforetakene.

- Det er gjennomført oppgavedeling og oppnådd reduserte ventetider og gode og effektive pasientforløp. 


\section{Forskning og innovasjon}

Langsiktige mål:

- Økt omfang av og implementering av klinisk pasientrettet forskning, helsetjenesteforskning og innovasjoner som bidrar til økt kvalitet, pasientsikkerhet, kostnadseffektivitet og mer helhetlige pasientforløp.

- Økt innovasjonseffekt av anskaffelser.

- Økt brukermedvirkning i innovasjon og i forskningens ulike faser.

- Økt antall pasienter som får tilbud om deltakelse i kliniske studier.

\section{Mål 2014:}

- Det er etablert system for særskilt relevansvurdering, i tillegg til kvalitetsvurdering, ved tildeling av tilskuddsmidler til forskningsprosjekter og som implementeres senest i 2015. Relevans- og kvalitetsvurderinger skal benyttes ved tildeling av 100 mill. kroner til nasjonale samarbeidsprosjekter på prioriterte fagområder, jf. kap 732, post 78.

- De regionale helseforetakene har i samarbeid initiert minst 3 nye kliniske multisenterstudier på biotilsvarende legemidler, ME (rituximab) og føflekkreft (ipilimumab) gjennom NorCRIN nettverket eller Nordic Trial Alliance i 2014.

- Felles årlig resultatrapport synliggjør eksempler på hvordan resultater fra forskning og innovasjon har bidratt til forbedret klinisk praksis/tjenesteutøvelse, i tillegg til øvrig resultatrapportering basert på nasjonalt tilgjengelig statistikk om forskning og innovasjonsaktivitet (jf. vedlegg 3 i oppdragsdokumentet for 2013).

\section{Styringsparametre 2014}

Som omtalt i kap. 1 er styringsparametre valgt for å gi et mest mulig samlet bilde av kvalitet, pasientsikkerhet og brukerorientering i tjenesten. Departementet vil i oppfølgingsmøtene med de regionale helseforetakene følge opp de valgte styringsparametrene samt andre kvalitetsindikatorer ved behov. Styret og ledelsen i Helse Sør-Øst RHF har et ansvar for å følge med på kvalitetsindikatorene som Helsedirektoratet publiserer og eventuelt iverksette tiltak for å forbedre kvaliteten i tjenestene.

Tabell 2. Styringsparametre 2014.

\begin{tabular}{|l|l|l|l|l|}
\hline Styringsparametre & Mål & Datakilde & $\begin{array}{l}\text { Rapporterings- } \\
\text { frekvens }\end{array}$ & $\begin{array}{l}\text { Nasjonal } \\
\text { kvalitets- } \\
\text { indikator }\end{array}$ \\
\hline \multicolumn{2}{|l|}{ Tilgjengelighet og brukerorientering } & \multicolumn{2}{|l|}{} \\
\hline $\begin{array}{l}\text { Gjennomsnittlig ventetid for } \\
\text { avviklede pasienter i } \\
\text { spesialisthelsetjenesten }\end{array}$ & $\begin{array}{l}\text { Under } 65 \\
\text { dager }\end{array}$ & Helsedirektoratet & Månedlig & Nei \\
\hline $\begin{array}{l}\text { Andel fristbrudd for } \\
\text { rettighetspasienter }\end{array}$ & $0 \%$ & Helsedirektoratet & Månedlig & Nei \\
\hline $\begin{array}{l}\text { Andel pasienter med } \\
\text { tykktarmkreft som får behandling } \\
\text { innen 20 virkedager }\end{array}$ & $80 \%$ & Helsedirektoratet & Tertialvis & Ja \\
\hline
\end{tabular}




\begin{tabular}{|c|c|c|c|c|}
\hline Styringsparametre & Mål & Datakilde & $\begin{array}{l}\text { Rapporterings- } \\
\text { frekvens }\end{array}$ & $\begin{array}{l}\text { Nasjonal } \\
\text { kvalitets- } \\
\text { indikator }\end{array}$ \\
\hline $\begin{array}{l}\text { Andel pasienter med lungekreft } \\
\text { som får behandling innen } 20 \\
\text { virkedager }\end{array}$ & $80 \%$ & Helsedirektoratet & Tertialvis & Ja \\
\hline $\begin{array}{l}\text { Andel pasienter med brystkreft } \\
\text { som får behandling innen } 20 \\
\text { virkedager }\end{array}$ & $80 \%$ & Helsedirektoratet & Tertialvis & Ja \\
\hline $\begin{array}{l}\text { Brukererfaringer for inneliggende } \\
\text { pasienter som får behandling i } \\
\text { somatiske sykehus }\end{array}$ & & $\begin{array}{l}\text { Nasjonalt } \\
\text { kunnskapssenter } \\
\text { for helsetjenesten }\end{array}$ & Årlig & $\mathrm{Ja}$ \\
\hline \multicolumn{5}{|l|}{ Kvalitet og pasientsikkerhet } \\
\hline 30 dagers totaloverlevelse & & $\begin{array}{l}\text { Nasjonalt } \\
\text { kunnskapssenter } \\
\text { for helsetjenesten }\end{array}$ & Årlig & Ja \\
\hline Sykehusinfeksjoner & & $\begin{array}{l}\text { Folkehelse- } \\
\text { instituttet }\end{array}$ & 2 ganger årlig & Ja \\
\hline $\begin{array}{l}\text { Andel tvangsinnleggelser (antall } \\
\text { per } 1000 \text { innbyggere i } \\
\text { helseregionen) }\end{array}$ & $\begin{array}{l}\text { Redusert } \\
\text { med } 5 \% \\
\text { sammenlig } \\
\text { net med } \\
2013\end{array}$ & Helsedirektoratet & Årlig & Ja \\
\hline $\begin{array}{l}\text { Andel reinnleggelser innen } 30 \\
\text { dager av eldre pasienter }\end{array}$ & & $\begin{array}{l}\text { Nasjonalt } \\
\text { kunnskapssenter } \\
\text { for helsetjenesten }\end{array}$ & Årlig & Ja \\
\hline $\begin{array}{l}\text { Andel pasienter 18-80 år innlagt } \\
\text { med blodpropp i hjernen som har } \\
\text { fått behandling med trombolyse }\end{array}$ & $20 \%$ & Helsedirektoratet & Tertialvis & $\mathrm{Ja}$ \\
\hline $\begin{array}{l}\text { Antall beslutninger i samarbeid } \\
\text { mellom de regionale } \\
\text { helseforetakene om å innføre eller } \\
\text { ikke innføre en ny metode, jf. } \\
\text { nasjonale metodevurderinger i } \\
\text { system for innføring av nye } \\
\text { metoder i spesialisthelsetjenesten }\end{array}$ & & $\begin{array}{l}\text { Regionale } \\
\text { helseforetak }\end{array}$ & Årlig & Nei \\
\hline $\begin{array}{l}\text { Antall gjennomførte mini } \\
\text { metodevurderinger som er sendt } \\
\text { til Kunnskapssenterets database }\end{array}$ & & $\begin{array}{l}\text { Nasjonalt } \\
\text { kunnskapssenter } \\
\text { for helsetjenesten }\end{array}$ & Årlig & Nei \\
\hline $\begin{array}{l}\text { Andel årsverk i psykisk helsevern } \\
\text { for voksne fordelt på henholdsvis } \\
\text { DPS og sykehus }\end{array}$ & & $\begin{array}{l}\text { Helsedirektoratet } \\
\text { (SSB) }\end{array}$ & Årlig & Nei \\
\hline $\begin{array}{l}\text { Fastlegers vurdering av } \\
\text { distriktspsykiatriske sentre }\end{array}$ & & $\begin{array}{l}\text { Nasjonalt } \\
\text { kunnskapssenter } \\
\text { for helsetjenesten }\end{array}$ & Årlig & Nei \\
\hline $\begin{array}{l}\text { Pasienterfaringer med } \\
\text { døgnopphold innen tverrfaglig } \\
\text { spesialisert rusbehandling }\end{array}$ & & $\begin{array}{l}\text { Nasjonalt } \\
\text { kunnskapssenter } \\
\text { for helsetjenesten }\end{array}$ & Årlig & Nei \\
\hline
\end{tabular}




\section{Oppfølging og rapportering}

Oppfølging gjennom plan- og meldingssystemet skal gi departementet informasjon om måloppnåelse på helsepolitiske mål. Det regionale helseforetaket har ansvar for at avvik fra gitte oppgaver og styringsparametre meldes departementet når slike avvik blir kjent.

I årlig melding skal det rapporteres på hvordan de regionale helseforetakene har fulgt opp Mål 2014 og Styringsparametre 2014. Det skal ikke rapporteres på langsiktige mål. Frist for innsendelse av styrets årlige melding er 15. mars 2015. Det vises til vedlegg 1 til foretaksprotokoll til Helse Sør-Øst RHF av 7. januar 2014 for nærmere informasjon på hva som skal rapporteres til Helse- og omsorgsdepartementet.

Rapporteringen skal skje elektronisk til postmottak@hod.dep.no med kopi til rapportering@hod.dep.no.

Oslo, 7. januar 2014

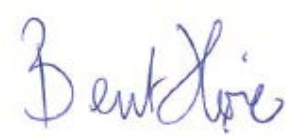

Bent Høie 


\section{Vedlegg 1 Utdanning av helsepersonell - dimensjonering}

\section{GRUNNUTDANNING omfatter studier ved videregående skoler, høgskoler og universiteter hvor}

elevene/lærlingene/studentene har helseforetakene som praksisarena. Fylkeskommunene har ansvar for de videregående skolene og for å sikre den enkeltes rett til slik utdanning. I de fleste fylker er det et opplæringskontor som i samarbeid med praksisarenaene skal sikre læreplasser i de yrkesfaglige utdanningene.

VIDEREUTDANNING omfatter legespesialistutdanningen og studier ved fagskoler, høgskoler og universiteter hvor studentene har helseforetakene som praksisarena (og arbeidsplass). Høgskoler som tilbyr videreutdanning, skal i forkant inngå avtaler med helseforetak om praksisplasser. Evt uenighet skal søkes løst i samarbeidsorganet.

Kunnskapsdepartementet har tidligere fastsatt årlige aktivitetskrav for enkelte studier ved utdanningsinstitusjonene. For 2014 endrer departementet styringen av dimensjonering for enkelte utdanninger fra aktivitetskrav til kandidatmåltall. Nedenfor gjengis Kunnskapsdepartementets forslag til kandidatmåltall for 2014. Det presiseres at kandidatmåltallet for den enkelte institusjon kun er et minstekrav. Endelige tall vil foreligge i KDs tildelingsbrev/tilskuddsbrev for 2014 til utdanningsinstitusjonene og kan formidles fra institusjonene i de regionale samarbeidsorganene.

\begin{tabular}{|c|c|c|c|c|c|c|c|c|c|}
\hline \multirow{2}{*}{$\begin{array}{l}\text { Helse } \\
\text { region }\end{array}$} & \multirow{2}{*}{$\begin{array}{l}\text { Høgskole } \\
\text { Universitet }\end{array}$} & \multicolumn{3}{|c|}{ Obligatorisk praksis } & \multicolumn{3}{|c|}{ Ikke obligatorisk praksis } & \multirow{2}{*}{$\begin{array}{l}\text { ABIOK- } \\
\text { sykepleie }\end{array}$} & \multirow[t]{2}{*}{ Jordmor } \\
\hline & & $\begin{array}{l}\text { Syke } \\
\text { pleie }\end{array}$ & $\begin{array}{l}\text { Radio } \\
\text { grafi }\end{array}$ & $\begin{array}{l}\text { Bio } \\
\text { ingeniør }\end{array}$ & $\begin{array}{l}\text { Fysio } \\
\text { terapi }\end{array}$ & $\begin{array}{l}\text { Ergo } \\
\text { terapi }\end{array}$ & $\begin{array}{l}\text { Verne } \\
\text { pleie }\end{array}$ & & \\
\hline \multirow{11}{*}{ 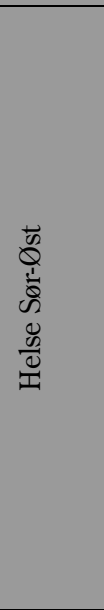 } & Gjøvik & 166 & 20 & & & & & 20 & \\
\hline & Hedmark & 164 & & & & & & 23 & \\
\hline & Lillehammer & & & & & & 57 & & \\
\hline & Oslo/Akershus & 492 & 34 & 50 & 134 & 51 & 141 & 120 & 34 \\
\hline & Ostfold & 109 & & 22 & & & 61 & 20 & \\
\hline & Diakonova & 83 & & & & & & 28 & \\
\hline & Lovisenberg diak. & 151 & & & & & & 48 & \\
\hline & Diakonhjemmet & 118 & & & & 24 & 97 & & \\
\hline & Univ. i Agder & 203 & & 21 & & & 35 & 25 & \\
\hline & Telemark & 103 & & & & & 45 & & \\
\hline & $\begin{array}{l}\text { Vestfold og } \\
\text { Buskerud }\end{array}$ & 233 & 20 & & & & & 51 & 20 \\
\hline \multirow{6}{*}{ 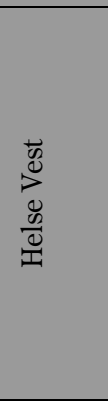 } & Bergen Høgskole & 172 & 25 & 23 & 57 & 29 & 71 & 41 & 32 \\
\hline & Sogn og Fjordane & 110 & & & & & 21 & 20 & \\
\hline & Univ. i Stavanger & 163 & & & & & & 34 & \\
\hline & Stord/Haugesund & 145 & & & & & & 20 & \\
\hline & $\begin{array}{l}\text { Betanien } \\
\text { Diakonale }\end{array}$ & 60 & & & & & & 22 & \\
\hline & $\begin{array}{l}\text { Haraldsplass } \\
\text { diakonale } \\
\text { høgskole }\end{array}$ & 70 & & & & & & & \\
\hline \multirow{4}{*}{ 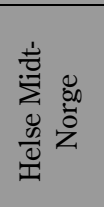 } & Molde & 79 & & & & & 38 & & \\
\hline & Nord-Trøndelag & 169 & & & & & 30 & & \\
\hline & Sør-Trøndelag & 180 & 31 & 49 & 52 & 57 & 70 & 83 & 25 \\
\hline & Ålesund & 104 & & 24 & & & & 31 & \\
\hline \multirow{6}{*}{ 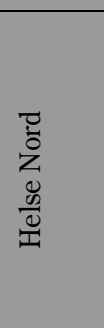 } & $\begin{array}{l}\text { Universitetet i } \\
\text { Nordland }\end{array}$ & 139 & & & & & & 26 & \\
\hline & Finnmark & 0 & & & & & & & \\
\hline & Harstad & 62 & & & & & 64 & & \\
\hline & Nesna & 20 & & & & & & & \\
\hline & Narvik & 33 & & & & & & & \\
\hline & Univ. i Tromsø & 166 & 24 & 20 & 25 & 20 & & 52 & 20 \\
\hline & & 3493 & 153 & 209 & 268 & 180 & 734 & 664 & 131 \\
\hline
\end{tabular}


Audiografutdanningen ved Høgskolen i Sør Trøndelag har kandidatmåltall 29.

Følgende kandidatmåltall er fastsatt for hhv medisin, psykologi og farmasi ved universitetene:

\begin{tabular}{|l|r|r|r|}
\hline Universitet & Medisin & Psykologi prof.utd. & Farmasi \\
\hline Universitetet i Oslo & 192 & 96 & 55 \\
\hline Universitetet i Bergen & 156 & 72 & 25 \\
\hline NTNU & 114 & 55 & 25 \\
\hline Universitet i Tromsø & 84 & 23 & \\
\hline
\end{tabular}

TURNUSTJENESTE er for noen yrkesgrupper et vilkår for å få autorisasjon. Helsedirektoratet (SAK) fastsetter hvor mange turnusplasser for leger og fysioterapeuter det skal legges til rette for og formidler dette i brev til hvert av RHFene. Turnustjenesten for leger ble endret med virkning fra 2013. Antallet turnusplasser for leger videreføres i 2014. Antallet turnusplasser for fysioterapeuter videreføres i tråd med økningen i 2013.

\section{FORDELING AV NYE LEGESTILLINGER}

Sentral fordeling av nye legestillinger opphørte 1. juli 2013. Oppretting av legestillinger skal fortsatt skje i tråd med behovene innen helseregionenes sørge-for ansvar, det helsepolitiske styringsbudskapet og de økonomiske rammer som er stilt til disposisjon. Gode lokale, regionale og nasjonale analyser av kompetansebehov framover skal legges til grunn for RHFenes fordeling av leger til HFene og mellom spesialiteter. RHFene skal særlig vurdere behovet for legestillinger til spesialiteter der utdanningskapasiteten i dag anses å være for lav og spesialiteter der behovet for legespesialister vil endre seg i årene fremover som en følge av befolkningsutvikling, sykdomsutvikling og organisatoriske endringer i helseforetakene. Stillinger i onkologi og patologi skal fortsatt prioriteres.

RHFene skal bidra til at Legestillingsregisteret i Helsedirektoratet til enhver tid er oppdatert. 